\title{
Influence of sperm number and seminal plasma on fertility of progestagen-treated sheep in confinement
}

\author{
G. A. Langford and G. J. Marcus \\ Animal Research Centre, Agriculture Canada, Ottawa, Ontario K1A OC6
}

\begin{abstract}
Summary. Progestagen-impregnated vaginal sponges + PMSG were used to synchronize oestrus in crossbred adult ewes which were inseminated $56 \mathrm{~h}$ after sponge removal with $0.5 \mathrm{ml}$ diluted semen containing $400,200,100,50$ or $25 \times 10^{6}$ spermatozoa per insemination. The diluent was skim milk-citrate or pooled seminal plasma.

There was no difference in reproductive performance due to the insemination medium. Fertility (no. of ewes lambing) after insemination of 400 or $200 \times 10^{6}$ spermatozoa was $68 \%$ and was similar to that observed after natural service at progestagen-induced oestrus. When $\leqslant 100 \times 10^{6}$ spermatozoa were inseminated, fertility fell markedly and the number of lambs per ewe inseminated decreased. A decrease in litter size also occurred. The data indicate that insemination of $200 \times 10^{6}$ spermatozoa, i.e. less than $10 \%$ of the number in a single ram ejaculate, allows normal conception rates in progestagen-treated ewes.
\end{abstract}

\section{Introduction}

High fertility when breeding ewes by artificial insemination (AI), requires that large numbers of spermatozoa (relative to the numbers used for cattle) be deposited into the external os of the cervix. This is because anatomical relations preclude the intrauterine route of insemination that can be used with much smaller numbers of spermatozoa in cows. The number of ewes which may be inseminated by a given ram is therefore limited.

Previous studies of the influence of sperm numbers (Salamon, 1962; Colas, Dauzier, Courot, Ortavant \& Signoret, 1968; Entwistle \& Martin, 1972; Schindler \& Amir, 1973; Zlatarev, 1976; Martin \& Watson, 1976) have been concerned with breeding sheep at natural oestrus. However, control of oestrus by using synthetic progestagen has become an important adjunct of large scale breeding by AI in many sheep production programmes. Although the use of progestagen may impair sperm transport and hence reduce fertility (Quinlivan \& Robinson, 1969; Hawk \& Conley, 1975), insemination of large numbers of spermatozoa overcomes this problem. Since there is no advantage in more than one insemination, given at the optimal time (Gordon, 1977; Colas, 1979; Langford, Ainsworth \& Wolynetz, 1982), it is desirable to determine the smallest number of spermatozoa which may be used in a single insemination without compromising fertility in progestagen-treated ewes. Accordingly, we have investigated the relation between the number of spermatozoa inseminated and fertility in crossbred ewes maintained and bred in total confinement. Because dilution alters the concentration of constituents of seminal plasma, such as prostaglandins (Eliasson \& Lindholmer, 1975), which may affect sperm motility, particularly at high dilutions (Blackshaw, 1953), we have also compared seminal plasma with skim milk-citrate as the medium for insemination. 


\section{Materials and Methods}

\section{Animals}

Three strains of crossbred adult ewes were maintained year-round in a total confinement system (Heaney et al., 1980). The lighting regimen was alternated at 4 -month intervals between an $18 \mathrm{~h}$ light: $6 \mathrm{~h}$ darkness (long day) cycle and a $10 \mathrm{~h}$ light: $14 \mathrm{~h}$ darkness (short day) cycle, to induce cyclic oestrous activity (Ortavant, 1977). The ewes were inseminated at the end of a 4-month short-day period, when they were all cyclic. Rams were kept separately in a constant environment of $16^{\circ} \mathrm{C}$ and the same lighting regimen as was used for the ewes, to control semen quality and maintain libido (Colas \& Courot, 1977). Semen was collected near the end of the short-day period.

\section{Insemination}

Vaginal sponges (Chronogest: Intervet S.A., Angers, France) impregnated with $40 \mathrm{mg}$ fluorogestone acetate (FGA) were inserted and left in place for 12 days to synchronize oestrus. At the time of sponge removal, ewes were given an intramuscular injection of 500 i.u. PMSG (Equinex: Ayerst Laboratories, Montreal, Canada) and artificially inseminated $56 \mathrm{~h}$ after sponge removal, in groups of 10 ewes for each ram. Data from ewes which had lost their sponge $(\mathrm{N}=$ 16), lacked cervical mucus and therefore were assumed not to be in oestrus at the time of $\mathrm{AI}$ $(\mathrm{N}=6)$ or died before lambing $(\mathrm{N}=4)$ were not used.

Semen was collected from trained rams with an artificial vagina, diluted at $30^{\circ} \mathrm{C}$ with skim milk-citrate to provide a sperm concentration of $800 \times 10^{6} / \mathrm{ml}$, cooled slowly and kept at $16^{\circ} \mathrm{C}$ for up to $6 \mathrm{~h}$ (Langford et al., 1979). Only rams with at least $70 \%$ motile spermatozoa and good progressive motility were used. Just before insemination 4 additional dilutions were made at $16^{\circ} \mathrm{C}$ using skim milk-citrate or seminal plasma to provide concentrations of $400,200,100$ and $50 \times 10^{6} / \mathrm{ml}$. Seminal plasma was prepared by centrifugation of individual semen collections from the donor rams $\left(700 \mathrm{~g}\right.$ at $4^{\circ} \mathrm{C}$ for $15 \mathrm{~min}$ ), pooling the supernatants and storing the plasma at $-20^{\circ} \mathrm{C}$ (for up to 2 weeks) until required. Semen from a given ram was tested at each dilution on 2 ewes. Ewes were confined in tilting squeeze chutes on a rotating platform with 3 chutes (Inskeep, 1974) and $0.5 \mathrm{ml}$ diluted semen was deposited into the first cervical fold or the external os.

On the 12th day after AI, the rams used for the inseminations were placed with their respective ewes for 9 days so that any ewes returning to oestrus would be inseminated naturally.

\section{Statistical analyses}

The results for fertility (no. of ewes lambing), litter size and fecundity (lambs born per ewe inseminated) were subjected to analysis of variance using a fitting constants procedure to accommodate unequal numbers of ewes in the different insemination groups (Harvey, 1960). Effects of strain, sperm number, rams within strain and insemination medium were considered, testing differences among means at the $1 \%$ probability level by the Newman-Keuls multiple range test (Steel \& Torrie, (1960).

\section{Results and Discussion}

The relation between number of spermatozoa inseminated and reproductive performance is shown in Table 1. There was no difference due to insemination medium. The fertility resulting from insemination of the highest sperm number was similar to that observed in the same flock 
after natural service at a single, induced oestrus ( $~ 67 \%$; Langford et al., 1979). This fertility did not decrease when the insemination dose was reduced to $200 \times 10^{6}$ spermatozoa, but decreased markedly $(P<0.01)$ when $\leqslant 100 \times 10^{6}$ spermatozoa were inseminated. A tendency to smaller litters when fewer spermatozoa were inseminated was not significant. Fecundity, a function of fertility and litter size, paralleled fertility. Among ewes inseminated with $100 \times 10^{6}$ spermatozoa in seminal plasma, only 8 of 31 lambed, but each had 2 or more lambs.

Table 1. Effect of sperm number and insemination medium on reproductive performance of ewes

\begin{tabular}{ccccccc}
\hline $\begin{array}{c}\text { Insemination } \\
\text { medium }\end{array}$ & $\begin{array}{c}\text { No. of sperm. } \\
\text { inseminated* } \\
\left(\times 10^{6}\right)\end{array}$ & $\begin{array}{c}\text { No. of ewes } \\
\text { inseminated }\end{array}$ & $\begin{array}{c}\text { No. of ewes } \\
\text { lambing } \\
(\%)\end{array}$ & $\begin{array}{c}\text { No. of } \\
\text { lambs }\end{array}$ & $\begin{array}{c}\text { Litter } \\
\text { size }\end{array}$ & Fecundity \\
\hline Skim milk-citrate & $400 \dagger$ & 29 & $20(69)$ & 50 & $2 \cdot 5$ & $1 \cdot 7$ \\
& 200 & 30 & $23(77)$ & 52 & $2 \cdot 3$ & $1 \cdot 7$ \\
& 100 & 31 & $13(42)$ & 25 & 1.9 & $0 \cdot 8$ \\
& 50 & 32 & $8(25)$ & 14 & $1 \cdot 8$ & $0 \cdot 4$ \\
Seminal plasma & 25 & 33 & $4(12)$ & 6 & $1 \cdot 5$ & $0 \cdot 2$ \\
& $400 \dagger$ & 29 & $18(62)$ & 41 & $2 \cdot 3$ & 1.4 \\
& 200 & 27 & $17(63)$ & 35 & $2 \cdot 1$ & $1 \cdot 2$ \\
& 100 & 31 & $8(26)$ & 22 & $2 \cdot 8 \ddagger$ & 0.7 \\
& 50 & 30 & $13(43)$ & 23 & 1.8 & $0 \cdot 7$ \\
& 25 & 32 & $9(28)$ & 17 & 1.9 & $0 \cdot 5$ \\
\hline
\end{tabular}

* In $0.5 \mathrm{ml}$ diluted semen deposited into first cervical fold or external os.

† Normal insemination dose at Animal Research Centre; standard dilution in skim milk-citrate.

$\ddagger$ All 8 ewes had more than one lamb.

The cumulative fertilities resulting from experimental treatment and natural service at a second oestrus (Text-fig. 1) indicated that there were no inherent fertility differences among the ewes assigned to different treatments.

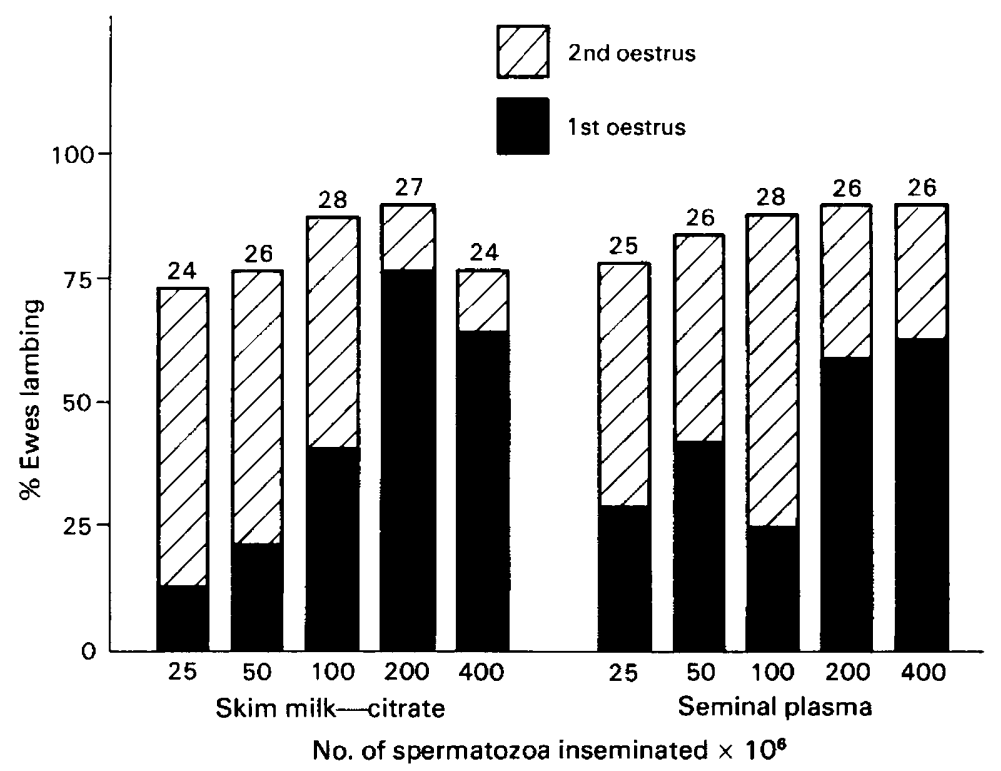

Text-fig. 1. Cumulative lambings (number above each bar) from inseminations at the first (AI) and second (natural) oestrus after synchronization of oestrus with progestagen-impregnated sponges. 
The smallest number of spermatozoa allowing maximal fertility in the present study $(200 \times$ $10^{6}$ ) is more than twice the number of spermatozoa reported to provide maximal fertility in ewes mated at natural oestrus (Salamon, 1962; Zlatarev, 1976; Schindler \& Amir, 1973; Entwistle \& Martin, 1972). Colas (1979) reported that insemination of 300-400 $\times 10^{6}$ spermatozoa stored for $<5 \mathrm{~h}$ in a skim milk-citrate diluent resulted in $65 \%$ fertility in progestagen-treated sheep on pasture. In the present study, $200 \times 10^{6}$ spermatozoa stored for $6 \mathrm{~h}$ gave equally good results. This dose is less than $10 \%$ of the number of spermatozoa in a single ejaculate.

When lower fertility may be expected, as with semen collected from rams during spring and summer or with frozen-thawed semen, some compensatory increase in the number of spermatozoa inseminated would be necessary. This was avoided in the present work by keeping rams in the same lighting regimen used to induce gonadal activity in ewes.

Although seminal plasma may be of little benefit as a sperm diluent (Gomes, 1977), this is relevant only for sperm storage. In this study, seminal plasma was used as a major component of the medium for insemination, to replace diluted putatively essential components, but we found no evidence for a requirement which is not met by skim milk-citrate diluent itself.

A factor not considered in the present study is that only a portion of the sperm suspension is retained in the cervix when a volume such as $0.5 \mathrm{ml}$ is inseminated. Good fertility has been obtained with less than $0.1 \mathrm{ml}$ extended semen (Entwistle \& Martin, 1972; Schindler \& Amir, 1973; Martin \& Watson, 1976) which suggests that further economies may be realized by determining the optimal volume of inseminate.

We thank Dr A. J. Hackett, Dr L. Ainsworth and Dr D. P. Heaney for assistance with the animals; Dr J. N. B. Shrestha and Dr A. J. Hackett for help with the statistical analyses; P. Panich for technical assistance; and J. Arcand, J. F. Hunter and D. Ostapyk for care of the sheep.

This is contribution No. 983 of the Animal Research Centre.

\section{References}

Blackshaw, A.W. (1953) The motility of ram and bull spermatozoa in dilute suspension. J. gen. Physiol. 36, 449-462.

Colas, G. (1979) Fertility in the ewe after artificial insemination with fresh and frozen semen at the induced oestrus, and influence of the photoperiod on the semen quality of the ram. Livest. Prod. Sci. 6, 153-166.

Colas, G. \& Courot, M. (1977) Production of spermatozoa, storage of semen and artificial insemination in the sheep. In Management of Reproduction in Sheep and Goats, pp. 31-40. University of Winsconsin, Madison.

Colas, G., Dauzier, L., Courot, M., Ortavant, R. \& Signoret, J.P. (1968) Resultats obtenus au cours de l'etude de quelques facteurs importants de l'insemination artificielle ovine. Annls Zootech. 17, 47-57.

Eliasson, R. \& Lindholmer, C. (1975) Human seminal plasma and sperm survival and transport. In The Biology of Spermatozoa, pp. 83-92. Eds E. S. E. Hafez \& C. G. Thibault. Karger, Basel.

Entwistle, K.W. \& Martin, I.C.A. (1972) Effects of the number of spermatozoa and of volume of diluted semen on fertility in the ewe. Aust. J. agric. Res. 23, $467-472$.

Gomes, W.R. (1977) Artificial insemination. In Reproduction in Domestic Animals, 3rd edn, pp.
257-284. Eds H. H. Cole \& P. T. Cupps. Academic Press, New York.

Gordon, I. (1977) Application of synchronization of estrus and ovulation in sheep. In Management of Reproduction in Sheep and Goats, pp. 15-30. University of Wisconsin, Madison.

Harvey, W.R. (1960) Least-squares analysis of data with unequal subclass numbers. UDSA, ARS 20-8.

Hawk, H.W. \& Conley, H.H. (1975) Involvement of the cervix in sperm transport failures in the reproductive tract of the ewe. Biol. Reprod. 13, 322-328.

Heaney, D.P., Ainsworth, L., Batra, T.R., Fiser, P.S., Hackett, A.J., Langford, G.A. \& Lee, A.J. (1980) Research for an intensive total confinement sheep production system. Agric. Can. Anim. Res. Inst. Tech. Bull. No. 2.

Inskeep, E.K. (1974) Artificial insemination and preservation of ram semen. Bull. W. Va agric. Exp. Stn 629, 22.

Langford, G.A., Marcus, G.J., Hackett, A.J., Ainsworth, L., Wolynetz, M.S. \& Peters, H.F. (1979) A comparison of fresh and frozen semen in the insemination of confined sheep. Can. J. Anim. Sci. 59, 911-916.

Langford, G.A., Ainsworth, L. \& Wolynetz, M.S. (1982) Reproductive response of progestagen-treated sheep in confinement to a single and double insemination. $J$. Anim. Sci. 54, 12-17. 
Martin, I.C.A. \& Watson, P.F. (1976) Artificial insemination of sheep: effects on fertility of number of spermatozoa inseminated and of storage of diluted semen for up to 18 hours at $5^{\circ} \mathrm{C}$. Theriogenology 5 , 29-35.

Ortavant, R. (1977) Photoperiodic regulation of reproduction in sheep. In Management of Reproduction in Sheep and Goats, pp. 58-71. University of Wisconsin, Madison.

Quinlivan, T.D. \& Robinson, T.J. (1969) Numbers of spermatozoa in the genital tract after artificial insemination of progestagen-treated ewes. J. Reprod. Fert. 19, 73-86.
Salamon, S. (1962) Studies on the artificial insemination of Merino sheep. A ust. J. agric. Res. 13, 1137-1150.

Sehindler, H. \& Amir, D. (1973) The conception rate of ewes in relation to sperm dose and time of insemination. J. Reprod. Fert. 34, 191-196.

Steel, R.G.D. \& Torrie, J.H. (1960) Principles and Procedures of Statistics, pp. 110-112. McGraw-Hill, New York.

Zlatarev, S.T. (1976) Optimal number of spermatozoa for artificial insemination of sheep with semen stored for 24 hours at $0-3^{\circ} \mathrm{C}$. In Proc. 8th Int. Congr. Anim. Reprod. \& A.l., Cracow vol. 4, pp. 1104 1107.

Received 31 July 1981 